\title{
Queering Engineering: A Critical Analysis of the Gendered Technical/Social Dualism in Engineering and Engineering Education Research
}

\section{Luis Leyva, Vanderbilt University}

Luis Leyva holds a Ph.D. degree in Mathematics Education with a certification in Women's and Gender Studies from Rutgers University. He will begin a tenure-track faculty position as Assistant Professor of Mathematics Education at Vanderbilt University in August 2016. As a 2015 Dissertation Fellow for the National Academy of Education and Spencer Foundation, Luis completed a dissertation that used intersectionality theory to examine mathematics as a social experience particularly in terms of gender and race among underrepresented college students in STEM (science, technology, engineering, and mathematics). He has presented his scholarship at research conferences organized by the American Educational Research Association, Association for the Study of Higher Education, and Out in STEM Incorporated. Luis holds professional experience in various STEM student support initiatives at Rutgers University including the STEM Talent Expansion Program, Upward Bound Math-Science, and Project Advancing Graduate Education. He is a certified K-12 mathematics teacher in New Jersey with a Master's degree in Mathematics Education and Bachelor's degree in Mathematics from Rutgers University.

\section{Mr. Jacob Massa, Rutgers University}

Jacob Massa is an undergraduate chemical engineering student in his senior year at Rutgers University. As an Aresty Research Fellow, National Space Grant Consortium Fellow, and James J. Slade Scholar, he has conducted research on catalytic light alkane dehydrogenation and methane reforming on $\mathrm{TiO} 2$ at Rutgers University. Additionally, Jacob has completed research on catalytic methane activation at the University of Houston under the NSF-funded Research Experience for Undergraduates program. He has presented research posters and given presentations of these works at many on-campus venues in addition to both regional and national conferences such as the American Institute of Chemical Engineers Annual Meeting. Jacob holds professional experience as a Teaching Assistant for introductory chemistry labs and peer mentor for various calculus courses at Rutgers University.

\section{Dan Battey, Rutgers University}

Dan Battey is an Associate Professor in Elementary Mathematics Education in the Graduate School of Education at Rutgers, the State University of New Jersey. He was previously faculty at Arizona State University and a postdoctoral fellow at UCLA in the Center for Teaching and Learning, Diversity in Mathematics Education (DiME). His work centers on engaging teachers in opportunities to learn within and from their practice in a way that sustains and generates change as well as challenges metanarratives that limit opportunities for African American and Latino students in mathematics. He is currently working on understanding mathematics education as a racialized space through researching relational interactions in classrooms. His work has been published in Teachers College Record, Educational Studies in Mathematics, Curriculum Inquiry, Urban Education, and Journal for Research in Mathematics among others. 


\title{
Queering Engineering: A Critical Analysis of the Gendered Technical/Social Dualism in Engineering and Engineering Education Research
}

\begin{abstract}
Wendy Faulkner first introduced the technical/social dualism in her 2000 article to detail engineering as a gendered space where technical skills are valued over social competence and thus deemed a masculinized trait. This paper draws on our review of research of peer-reviewed journal articles, handbook chapters, and refereed conference proceedings that cite Faulkner's article to critically examine the variation of using the technical/social dualism to explore engineering as a gendered field of study. Faulkner's three-tiered analytical framework (division of labor, symbols, and identities) was adopted in our review to document the extent to which the gendered mappings of the technical/social dualism onto heterosexual masculinity/femininity have been challenged in order to further broaden participation among women and lesbian, gay, bisexual, trans*, queer/questioning, and other (LGBTQ+) individuals. A subset of findings from the review presented in this paper highlight the need for future ethnographic analyses that advance Faulkner's destabilizing of the technical/social dualism. This allows for the detailing of in-the-moment gendered engineering experiences among women and LGBTQ+ individuals at multiple intersections of their gender, sexuality, and other social identities.
\end{abstract}

\section{Introduction}

Scholars use various dualisms (e.g., abstract/concrete, rational/irrational, technical/social) to explore engineering as a gendered space in terms of representation, practices, and identities. ${ }^{4,6}$, 11,18 The technical/social dualism is well documented in the research literature with over 200 scholarly citations (84 peer-reviewed) of Wendy Faulkner's 2000 journal article where the dualism was first introduced. ${ }^{11}$ Faulkner argued that gender and technology (including engineering) are co-produced such that a gendered disparity exists between the image and practice of engineering. ${ }^{11}$ More specifically, the technical end of the dualism maps onto independent tool and technology use for practical purposes as a more valued and masculinized form of engagement, or "masculine instrumentalism." The social end of the dualism maps onto the ideas of communication, interpersonal relationships, and expression of emotion in engineering as a less valued and feminine forms of engagement, or "feminine expressiveness."

However, such dualistic thinking does not reflect the blend of technical and social practices in doing engineering, or what Faulkner referred to as the heterogeneity of the actual engineering practice. ${ }^{11}$ Faulkner asserted that the mapping between the technical/social and masculine instrumentalism/feminine expressiveness is heterosexist, or prejudiced and discriminatory toward gender-nonconforming individuals. This results in gender in/authenticity among women as well as lesbian, gay, bisexual, trans*, queer/questioning, and other (LGBTQ+) individuals who feel out of place in engineering as a field masculinized heteronormatively, or privileging heterosexual men who are cis-gendered (in this case, having gender identities aligned with their male biological sex).

The technical/social dualism genders engineering in three ways: (i) division of labor and styles of work, (ii) symbols, and (iii) personal and professional identities. Values of masculinized 
technical aspects of engineering structure a gendered hierarchy, or division of labor, that separates who can and cannot do engineering with non-technical (or social) styles of work deemed feminine and thus not mapping onto "real" engineering. ${ }^{15}$ At the symbolic level, this prioritization of the technical keeps the "equation of technology and masculinity" intact vis-à-vis the perpetuation of masculinized perspectives on doing engineering. ${ }^{11}$ The "gendered contradictions" between engineering images (or symbols) and practices produce a masculinized, specialist culture in the discipline and profession that limits women's and LGBTQ+ individuals' opportunities for co-constructing positive gender and engineering identities. ${ }^{11}$

Such marginalizing influences of the technical/social dualism brought Faulkner to posit that the heterosexist ideology underpinning the dualism must be destabilized in order to broaden opportunities in engineering for women and gender-nonconforming populations including members of the LGBTQ+ community. ${ }^{11}$ Despite this call for challenging such heterosexism, much research drawing on Faulkner's 2000 article minimally disrupts the mapping from technical/social to heteronormative masculinity/femininity in exploring engineering as a gendered discipline and career. ${ }^{11,12}$ Only a small subset of this research examines gender issues in relation to underrepresented LGBTQ+ individuals and the complexities of their "boundary work," the negotiations of the heterosexist technical/social dualism with their identities while navigating heteronormatively gendered academic and professional engineering spaces. ${ }^{6,12,13,32}$

This paper draws on a review of research that cited Faulkner's 2000 article to critically examine the varied use of the technical/social dualism in exploring engineering as a gendered domain. ${ }^{11,23}$ In particular, we adopt Faulkner's three-tiered analytical framework of engineering as a gendered space to document the extent to which the heterosexist mappings of the technical/social dualism have been challenged in extant research. ${ }^{11}$ Our work aims to highlight the room for further analysis that advances Faulkner's call for feminist destabilizing of the technical/social dualism and thus further centers the experiences and identities among LGBTQ+ populations. ${ }^{6,11}$

\section{Methods}

Our review of research focused on literature that cited Faulkner's article where the technical/social dualism was introduced to critically examine how the dualism has been adopted in research on engineering and engineering education. This resulted in 237 search results on Google Scholar. To pursue a comprehensive review of literature with broad impact, we then limited our analysis to peer-reviewed works including journal articles, handbook chapters, and refereed conference proceedings. This reduced the search results to 102. Finally, we identified literature from these results attending to issues of gender. This resulted in the 35 peer-reviewed texts for our analysis including 20 journal articles on empirical studies, 6 conceptual pieces published as journal articles, and 9 conference proceedings on empirical and conceptual work.

Drawing on Weaver-Hightower's literature review methodology, we grouped the 35 pieces using three grounded categories based on Faulkner's three-tiered analytical framework: (i) division of labor, (ii) symbols, and (iii) professional and personal identities. ${ }^{11,31}$ Literature grouped as division of labor texts explored the gendered organization and nature of work in engineering education and professions. The texts under the symbols category focused on how the technical/social dualism produces gendered images and perspectives that masculinize 
engineering as a field of study and career. Lastly, the works under the professional and personal identities (or identities) category attended to how individuals negotiate their social identities, including gender and sexuality, with institutional structures and interpersonal relations that shape gendered notions of who can and cannot do engineering.

This review aims to inform more nuanced analyses of gender in future research as well as the adoption of gender-inclusive practices in undergraduate engineering education and professions. We, therefore, specifically focus on literature under the division of labor and identities categories where the technical/social dualism is applied to make meaning of empirical data on the gendered interplay of institutions and individuals' everyday experiences in engineering. Our analytical categorization of the reviewed literature resulted in the following distribution: 10 texts under division of labor, 15 texts under symbols, and 10 texts under identities. Appendix 1 presents a listing of the reviewed literature for the division of labor and identities categories including their respective number of citations as of February 2016, study contexts, and participant profiles.

Our analysis of the research examines the extent to which Faulkner's call for disrupting the heterosexist mapping of the technical/social dualism to masculine instrumentalism/feminine expressiveness was pursued. ${ }^{11}$ This allowed us to trace the intellectual development of gender as a unit of analysis and thus critically consider our current understandings of the experiences and opportunities for success among LGBTQ+ individuals.

The following section presents a review of representative texts across the division of labor and identities categories that both highlights and critiques their respective contributions to the study of gender in engineering and engineering education. Representative texts for each of the two categories were purposefully selected to capture the variation in their use of the technical/social dualism for examining gender empirically and conceptually, particularly in relation to Faulkner's call for the destabilizing of the dualism's heterosexist underpinnings. ${ }^{11}$

\section{Review of Literature}

\section{Division of Labor}

Literature grouped under the division of labor category draws on the technical/social dualism to explore the gendered nature of institutional structures (e.g., curriculum, school mission statements, salary) and interpersonal dynamics (e.g., tinkering, job expectations) that masculinize engineering. 2, 4, 9, 17 Such masculinization is argued to explain women's underrepresentation in

engineering careers. ${ }^{17,24,28}$ Lynch and Nowosenetz, for example, drew on the gendered dualism to discuss how women are perceived as more adept in careers that prioritize social interactions rather than technical skills like in engineering. ${ }^{24}$ Additionally, scholars drew on Faulkner's discussion of how the technical/social dualism produces gendered hierarchies to illustrate how masculinized values of technical knowledge and skills are deemed aspects of "real" engineering work that in turn marginalize women's contributions as engineering students and professionals. 4 , 11, 16, 17 Cech identified undergraduate education as the starting point for such gendering of the engineering field vis-à-vis the technical/social dualism that problematically presents students with an inaccurate of idea of engineering as a strictly technical domain with minimal-to-no need for social and emotional engagement." This is what Faulkner refers to as the "gendered 
contradiction" between the specialist image and heterogeneous practices in engineering that must be addressed. ${ }^{11}$

Thus, scholars have adopted the technical/social dualism as an analytical device to unpack these gendered contradictions and thus capture the heterogeneity of practice for being successful as engineering students and professionals. ${ }^{4,5,20}$ In an online survey study of 288 undergraduate engineering majors across four institutions, Cech and colleagues attributed student participants' persistence as engineering majors to professional role confidence. ${ }^{5}$ They defined professional role confidence as "individuals' confidence in their ability to successfully fulfill the roles, competencies, and identity features of a profession." Cech and colleagues argued that women's lack of opportunities in developing professional role confidence in male-dominated engineering contexts explain women's low retention in the engineering pipeline. ${ }^{5}$ Although this confidence is presented as a masculinized construct, it is noteworthy how Cech and colleagues identified relational confidence -- a social and thus feminine skill according to the technical/social dualism -- as a key dimension of professional role confidence in engineering. ${ }^{5}$ Even though Cech and colleagues drew heteronormatively gendered conclusions regarding women's underrepresentation in engineering, we still see how they used the technical/social dualism to argue for engineering success as a heterogeneous endeavor involving both content expertise and relationship development. ${ }^{5}$

Similarly, Lagesen and Sørensen's interview study of over 25 Norwegian software engineering consultants (50\% women) adopted the technical/social dualism to examine the heterogeneity of the consultants' professional communication practices. ${ }^{20}$ They discussed how the consultants' communication was not a strictly social practice as they also incorporated technical expertise to support clients. ${ }^{20}$ Lagesen and Sørensen described consultants' reflections on their work, "They did not directly invoke the traditional social/technical binary like Faulkner (2000) observed. Instead, they insisted that their technical knowledge formed the basis of their interaction with customers and their ability to find good solutions". ${ }^{23}$ Much like Cech and colleagues' finding on the value of coupling relational confidence with technical command, the consultants' professional success in Lagesen and Sørensen's study was characterized as a heterogeneous form of communication that leveraged programming and other forms of content expertise as "linguistic resource[s]." 5, 20 These two studies, therefore, challenged the mutual exclusivity of technical and social practices under the technical/social dualism and thus highlighted the heterogeneity of the actual engineering practice.

Looking across the division of labor literature, scholars illustrate the co-production of gender and technology (including engineering) via the technical/social dualism while disrupting how, as Buck and colleagues described, "organizational structures and occupational ethos of engineering perpetuate this co-constituency." 2 This body of literature also empirically and conceptually advanced Faulkner's call for destabilizing the "equation of technology and masculinity" to overcome the gendered contradictions between the image and practice of doing engineering. ${ }^{11}$ Despite these advances, the division of labor scholarship limited its study of gender to sex-based analyses through group comparisons between women's and men's engineering educational experiences and professional opportunities. ${ }^{32}$ Such sex-based analyses, however, prevented scholars from attending to what Faulkner refers to as the "boundary work" around the technical/social dualism among individual women and men. ${ }^{16}$ Exploring the within-group 
variation of women's and men's engagement with the dualism offers insight into different strategies that marginalized populations, including women and LGBTQ+ individuals, adopt in navigating the heteronormatively masculinized spaces of engineering. This, in turn, challenges the long-standing narrative of all women, as Cech described, "occupy[ing] the out group" in engineering due to their gendered misalignment with technical prowess inscribed as a masculine trait. ${ }^{4}$ Furthermore, the adoption of gender-based (as opposed to sex-based) analyses in the literature would allow for considerations of how institutional organizations and policies in engineering are heteronormatively gendered and impact LGBTQ+ individuals in varying ways an "under-researched theme in the gendering of technology," according to Faulkner. ${ }^{11}$

\section{Professional and Personal Identities}

Literature grouped under the identities category addresses this need for examining individuals' negotiations of their gender and sexual identities with the notion of gender in/authenticity framed by the technical/social dualism. ${ }^{15}$ This includes empirical work that documented individual women and men engineers' strategies in co-constructing gender and engineering identities. ${ }^{14,18 \text {, }}$ ${ }^{19,29}$ In addition, this body of scholarship investigated institutional forms of heteronormativity across engineering departments and workplaces with implications for building more inclusive educational and professional opportunities among LGBTQ+ populations. ${ }^{6,7,32}$

To document the gendered variation in decisions for pursuing engineering, Holth collected life narratives via interviews with 24 undergraduate engineering students ( 15 women and 9 men) and 22 engineering graduates working in an information technology consulting company (11 women and $11 \mathrm{men}) .{ }^{18}$ Holth noted how participants' reflections on their engineering experiences invert the ways in which the technical/social and other dualisms raised by Faulkner are gendered. ${ }^{11,18}$ More specifically, Holth discussed how women engineers (the "rational women") pursued engineering for instrumental purposes (e.g., job opportunities) while the men engineers (the "passionate men") expressed love for the discipline as playing a major role in their decisions. ${ }^{18}$ Thus, we see how these successful women and men engineers engaged in masculine instrumentalism and feminine expressiveness respectively under the technical/social dualism. Holth's finding of such inverted ways of "doing gender" among participants' choices of engineering, therefore, builds on Faulkner's notion of gendered contradictions to broaden meanings of success in engineering and engineering education. ${ }^{11,18}$

Kyriakidou as well as Saavedra and colleagues pursued more focused analyses of within-group variation in gendered constructions of engineering identities through interview studies with women engineers. ${ }^{19,}{ }^{29}$ Kyriakidou collected narratives from 33 successful Greek women engineers holding managerial positions to detail their gendered professional identity constructions. ${ }^{19}$ Findings captured how these women engineers engaged in discursive acts of redefining: (i) their gendered disadvantage, (ii) the masculinized professional rhetoric in engineering, and (iii) themselves in different moments and contexts. ${ }^{19}$ These discursive moves are ways in which the women engineers built positive professional identities without sacrificing their femininities or fully assimilating to valued forms of masculinity in the workplace.

In contrast, Saavedra and colleagues' analysis of interviews with 39 women engineers resulted in four discursive strategies for navigating the masculinized engineering domain: (i) disguising 
differences with similarities, (ii) assuming differences by valuing femininity, (iii) assuming differences and inequalities, and (iv) maintaining limits and respect. ${ }^{29}$ These strategies problematically perpetuated Faulkner's technical/social dualism that privilege masculinity across engineering spaces in light of how the women engineers assimilated to masculine norms and values, distinguished themselves via an essentialist view of femininity, and/or perceived engineering as a gender-neutral space with equal opportunities for women and men. ${ }^{11}$

The contrasting nature of the findings from these two studies on women engineers captures the gendered variation of individual engineering experiences that cannot be documented through sex-based group comparisons as adopted in the division of labor work. At the same time, both studies illustrate women engineers' emotional labor of protecting and negotiating their feminine identities across institutional contexts masculinized through the technical/social and other gendered dualisms. This points to a need for scholarship that documents forms of institutional masculinization in engineering to promote more gender-inclusive educational and workplace environments, thus broadening the notion of gender authenticity in engineering so marginalized group members have more opportunities to see themselves and be positioned as "real" engineers.

Faulkner took up this task by moving beyond post-hoc analyses via interviews and focus groups and pursuing in-the-moment analyses of gendered engineering experiences. ${ }^{14}$ Her ethnographic work explored the gendered dynamics among 52 engineers (33 women and 19 men) across three companies to detail what she calls the engineering workplace culture, "a rather amorphous collection of practices which characterise everyday interactions between engineers." 14 In doing this, Faulkner collected both interview and observation data to "bring a gender 'gaze' to an ethnographic investigation of engineering practices, cultures, and identities" that she claimed to be largely absent in extant research. ${ }^{14}$ Her findings shed light on gender-exclusive dynamics such as fraternizing and other forms of homosocial bonding (e.g., "rituals of tinkering"), strong social networks particularly among men, and heteronormatively sexual and homophobic humor. At the same time, Faulkner identified gender-inclusive practices in the workplace cultures that she saw as "pointers to change" for more diverse, supportive engineering work environments that promote positive co-constructions of gender and engineering identities. ${ }^{14}$ Some of these inclusive practices were respectful interactions, mixed-sex social networks, and avoidance of and directly challenging offensive humor. It is important to note Faulkner's non-binary conceptualization of gender in her ethnographic analysis that, unlike the division of labor scholarship, disrupts the heteronormative masculine/feminine mappings of the technical/social dualism in engineering. Faulkner wrote, "Not all men are comfortable in engineering workplace cultures, and not all women are marginalised. Rather, the analysis reveals the doing of diverse gender identities and dynamics, albeit some more normative or hegemonic than others." 14

Cech and Waidzunas adopted the previously discussed identities works' analytical focus on a single marginalized group and a non-binary, non-heterosexist theorization of gender to detail undergraduate engineering as a heteronormatively gendered space. The study involved 13 LGB (lesbian, gay, and bisexual) students at a competitive, public university in the United States. . $^{7}$ Taking up Faulkner's call for disrupting the heteronormatively gendered nature of the technical/social dualism, Cech and Waidzunas argued that the dualism does not neatly map onto the heterosexual/homosexual binary considering the diverse gender performances of LGB individuals (e.g., feminine gay men, masculine lesbian women). ${ }^{6,7,11}$ This work also draws a 
parallel between women's gendered feelings of invisibility and inauthenticity (documented in the division of labor and prior identities research) and that experienced by "out" LGB engineers. Cech and Waidzunas used interview and focus group data to detail LGB undergraduate engineering students' strategies in negotiating their personal identities while navigating the heteronormative university contexts of engineering. ${ }^{6,7}$ These strategies included "passing" as heterosexuals, "covering" their LGB markers, and acquiring expertise to protect their competence and contributions. Cech and Waidzunas discussed how these strategies capture the privileging of heteronormative forms of masculinity vis-à-vis the technical/social dualism as LGB students found themselves not only needing to demonstrate technical prowess as a protective mechanism, but also downplaying their gender and sexual identities deemed more social in nature and thus inappropriate in the context of doing their engineering work. ${ }^{6,7}$

This corroborated Yoder and Mattheis' findings from an online survey study on the lived experiences of 1427 lesbian, gay, bisexual, trans*, queer, and asexual (LGBTQA) individuals working in STEM (science, technology, engineering, and mathematics) fields. ${ }^{32}$ Yoder and Mattheis reported that survey respondents more frequently indicated that their colleagues were unaware of their LGBTQA identities than not being "out" in personal contexts. ${ }^{32}$ More than half of respondents identified as being "out" professionally, of which many reported having strong representation of women colleagues and/or support opportunities addressing needs of LGBTQA individuals. In alignment with Faulkner's destabilizing of the technical/social dualism's heterosexist mapping onto heteronormative masculinity/femininity, Yoder and Mattheis hypothesized how more balanced gender representation or "some broader factor of tolerance for non-masculine gender expression" in workplace contexts can contribute to more affirming, supportive experiences for LGBTQA and heterosexual, cis-gendered women in engineering. ${ }^{11,32}$ These hypotheses reflect more nuanced considerations of gender at intersections with sexual identity and thus point to a need for future scholarship that explores institutional practices (e.g., hiring processes, undergraduate mentoring initiatives) that promote inclusivity and support for LGBTQ+ populations in engineering careers and higher education.

Looking across the identities literature, scholars responded to Faulkner's concern about minimal scholarship exploring the development of engineering identities through gendered negotiations of the technical/social dualism. ${ }^{13}$ Such analyses warranted a methodological shift from that adopted in the division of labor scholarship to more focused explorations of within-group variation among individual women's and men's feelings of gendered authenticity as engineers across heteronormatively masculinized spaces including university departments and companies. Despite this advance, a large proportion of the identities literature (except Faulkner's ethnographic study) adopted post-hoc analyses of individuals' engineering experiences. This, therefore, limited opportunities for detailing everyday interactions and practices that dynamically produce heteronormatively gendered engineering experiences for women and LGBTQ+ individuals. From a conceptual standpoint, the identities literature adopted a feminist theorization of gender as a social construct varying across individuals and contexts - an advance from the binary, sex-based analyses in the division of labor work that problematically perpetuated the masculine/feminine dualisms of engineering. The identities scholarship also attended to intersections of gender and sexuality that disrupted heterosexist mappings of the technical/social dualism. However, there remains analytical space for documenting gendered engineering experiences at other intersections of identity (e.g., race/ethnicity, class). 


\section{Conclusion}

This review of research captures the variation in how Faulkner's highly-cited article that introduced the technical/social dualism has been used in extant scholarship for detailing engineering and engineering education as heteronormatively masculinized, white spaces. ${ }^{11,22}$ Scholars assert that undergraduate education is a time when individuals, by and large, are presented with gendered contradictions between the image and practice of engineering as framed by the technical/social dualism. ${ }^{4}{ }^{6}$ With the marginalizing impact of such gendered perspectives in engineering on women and LGBTQ+ populations, it is important for future research to detail students' undergraduate engineering experiences both in and out of the classroom to ensure broadened opportunities for participation across the engineering pipeline. . $25,26,27$

As outlined in this paper, the division of labor literature highlights the heterogeneity of engineering practices while the identities literature advances the study of gender as a sexualized social construct in engineering. These analytical insights equip future engineering education researchers with the methodological and theoretical tools for documenting ways to establish more gender-inclusive learning environments and student support opportunities at the postsecondary level. ${ }^{6,10,16}$ Exploring individuals' engineering experiences at intersections of gender and sexuality with other social identities (e.g., race/ethnicity, class) offers more nuanced insights into how women, LGBTQ+ populations, and other marginalized student groups differentially negotiate their identities with the culture of engineering that, as Yoder and Mattheis described, is "stereotypically dominated by White, heterosexual men."

Additionally, the continued use of ethnographic methodology provides an analytical glimpse into the strategies that intersectionally marginalized individuals, including subgroups of the LGBTQ+ community (e.g., queer people of color), adopt in navigating heteronormatively masculinized institutional spaces and gendered microaggressions in undergraduate engineering education. ${ }^{14,27}$ Findings from Faulkner's ethnographic work, for example, captured how these institutional contexts mediated the establishment of gender-inclusive workplace cultures among women and men engineers. ${ }^{17}$ We posit that such ethnographic analyses hold empirical promise in documenting the in-the-moment interplay of institutional structures and LGBTQ+ individuals' engineering experiences in education and workplace settings. This would, in turn, complement findings from post-hoc analyses of LGBTQ+ engineering students' and professionals' experiences to inform gender-inclusive institutional change in departments and companies. ${ }^{6,7,32}$

Insights from such future lines of scholarship can inform engineering educators' pedagogical approaches in strengthening the inclusivity of classroom learning experiences. Such practices include (i) designing curricula and assessments that reflect the heterogeneity of engineering professional practices and (ii) challenging gendered status in the classroom through structured groupwork and equitable acknowledgment of students' contributions. In addition, this future research can guide STEM support program directors' development of co-curricular campus initiatives that addresses both academic (or technical) and social needs of LGBTQ + and other marginalized students. Partnerships between engineering departments and university chapters of organizations like Out in STEM and the National Organizations of Gay and Lesbian Scientists and Technical Professionals, for instance, can provide LGBTQ+ students with a network of faculty and peers to advance their co-constructions of positive engineering and gender identities. 


\section{Appendix 1}

\begin{tabular}{|c|c|c|c|c|c|}
\hline Category & $\begin{array}{l}\text { Examples } \\
\text { (* denotes texts } \\
\text { in review) }\end{array}$ & $\begin{array}{l}\text { Number } \\
\text { of } \\
\text { Citations }\end{array}$ & Source & Context & Participants \\
\hline \multirow[t]{4}{*}{$\begin{array}{c}\text { Division of } \\
\text { Labor }\end{array}$} & $\begin{array}{l}\text { Faulkner } \\
(2007)\end{array}$ & 215 & $\begin{array}{c}\text { Social Studies of } \\
\text { Science }\end{array}$ & $\begin{array}{c}2 \text { design } \\
\text { engineering } \\
\text { consulting } \\
\text { companies in } \\
\text { U.K. }\end{array}$ & $\begin{array}{l}6 \text { engineers } \\
\text { (Karen and } \\
\text { Fraser) }\end{array}$ \\
\hline & $\begin{array}{l}\text { de Pillis \& de } \\
\text { Pillis (2008) }\end{array}$ & 16 & $\begin{array}{c}\text { Journal of } \\
\text { Diversity in } \\
\text { Higher } \\
\text { Education }\end{array}$ & $\begin{array}{c}\text { Public } \\
\text { university; } \\
\text { Mission } \\
\text { statements from } \\
\text { top } 10 \\
\text { undergraduate } \\
\text { liberal arts } \\
\text { colleges and } \\
\text { engineering } \\
\text { programs in U.S. }\end{array}$ & $\begin{array}{c}103 \\
\text { undergraduate } \\
\text { students (56 } \\
\text { women, } 47 \\
\text { men) enrolled } \\
\text { introductory } \\
\text { business }\end{array}$ \\
\hline & $\begin{array}{c}\text { Foor \& Walden } \\
(2009)\end{array}$ & 25 & NWSA Journal & $\begin{array}{c}\text { University of } \\
\text { Oklahoma }\end{array}$ & $\begin{array}{c}118 \\
\text { undergraduate } \\
\text { engineering } \\
\text { students (55 } \\
\text { women, } 63 \\
\text { men) }\end{array}$ \\
\hline & $\begin{array}{l}\text { Lagesen \& } \\
\text { Sørensen } \\
(2009)^{*}\end{array}$ & 9 & $\begin{array}{l}\text { Engineering } \\
\text { Studies }\end{array}$ & $\begin{array}{c}\text { Norwegian } \\
\text { University of } \\
\text { Science \& } \\
\text { Technology and } \\
3 \text { Norwegian } \\
\text { software firms }\end{array}$ & $\begin{array}{l}\text { 8-11 employees } \\
\text { from each } \\
\text { companies (half } \\
\text { were women) }\end{array}$ \\
\hline
\end{tabular}




\begin{tabular}{|c|c|c|c|c|}
\hline $\begin{array}{c}\text { Lynch \& } \\
\text { Nowosenetz } \\
\text { (2009) }\end{array}$ & 22 & $\begin{array}{l}\text { Gender and } \\
\text { Education }\end{array}$ & $\begin{array}{l}\text { Urban South } \\
\text { African } \\
\text { university in } \\
\text { Gauteng }\end{array}$ & $\begin{array}{l}24 \text { Black and } \\
\text { white SET } \\
\text { undergraduate } \\
\text { women and } \\
\text { men }\end{array}$ \\
\hline $\begin{array}{c}\text { Cech, } \\
\text { Rubineau, } \\
\text { Silbey, \& Seron } \\
\text { (2011) }\end{array}$ & 131 & $\begin{array}{c}\text { American } \\
\text { Sociological } \\
\text { Association }\end{array}$ & $\begin{array}{l}\text { Massachusetts } \\
\text { Institute of } \\
\text { Technology, } \\
\text { University of } \\
\text { Massachusetts at } \\
\text { Amherst, Olin } \\
\text { College of } \\
\text { Engineering, } \\
\text { Smith College } \\
\end{array}$ & $\begin{array}{c}288 \\
\text { undergraduate } \\
\text { engineering } \\
\text { students across } \\
4 \text { U.S. } \\
\text { institutions }\end{array}$ \\
\hline $\begin{array}{l}\text { Hatmaker } \\
(2012)\end{array}$ & 5 & $\begin{array}{c}\text { Engineering } \\
\text { Studies }\end{array}$ & United States & $\begin{array}{l}44 \text { women and } \\
14 \text { men } \\
\text { undergraduate } \\
\text { engineering } \\
\text { graduates }\end{array}$ \\
\hline Roeser (2012) & 21 & $\begin{array}{c}\text { Science and } \\
\text { Engineering } \\
\text { Ethics }\end{array}$ & $\mathrm{N} / \mathrm{A}$ & $\mathrm{N} / \mathrm{A}$ \\
\hline $\operatorname{Cech}(2013)^{*}$ & 12 & Social Forces & $\begin{array}{l}2003 \text { National } \\
\text { Survey of } \\
\text { College } \\
\text { Graduates } \\
\text { (National } \\
\text { Science } \\
\text { Foundation) }\end{array}$ & $\begin{array}{c}9936 \text { survey } \\
\text { respondents } \\
\text { (1120 women } \\
\text { and } 8816 \text { men }) \\
\text { including } \\
\text { biologists, } \\
\text { physical } \\
\text { scientists, and } \\
\text { other non-SE } \\
\text { professionals }\end{array}$ \\
\hline
\end{tabular}




\begin{tabular}{|c|c|c|c|c|c|}
\hline & $\begin{array}{c}\text { Buck, } \\
\text { Gammon, \& } \\
\text { Preston (2014) }\end{array}$ & 5 & Hypatia & N/A & $\mathrm{N} / \mathrm{A}$ \\
\hline \multirow[t]{3}{*}{$\begin{array}{l}\text { Professional } \\
\text { and Personal } \\
\text { Identities }\end{array}$} & $\begin{array}{l}\text { Du \& Kolmos } \\
(2007)\end{array}$ & 265 & $\begin{array}{l}\text { Proceedings from } \\
2007 \text { American } \\
\text { Society for } \\
\text { Engineering } \\
\text { Education Annual } \\
\text { Conference \& } \\
\text { Exposition }\end{array}$ & Denmark & $\begin{array}{c}2 \text { studies: } \\
17 \\
\text { undergraduate } \\
\text { engineering } \\
\text { students (13 } \\
\text { women, } 4 \\
\text { men); } 70 \\
\text { undergraduate } \\
\text { engineering } \\
\text { students (28 } \\
\text { women, } 32 \\
\text { men) }\end{array}$ \\
\hline & $\begin{array}{c}\text { Sagebiel, } \\
\text { Dahmen, } \\
\text { Davidsson, } \\
\text { Godfroy-Genin, } \\
\text { Rommes, Taler, } \\
\text { \& Urbancikova } \\
(2008)\end{array}$ & 8 & $\begin{array}{l}\text { Proceedings from } \\
\text { the } 2008 \text { SEFI } \\
\text { Annual Conference }\end{array}$ & $\begin{array}{c}\text { Austria, } \\
\text { France, } \\
\text { Germany, } \\
\text { Netherlands, } \\
\text { Slovakia, } \\
\text { Spain, Sweden }\end{array}$ & $\begin{array}{l}\text { Participants in } \\
\text { MOTIVATIO } \\
\text { N project }\end{array}$ \\
\hline & $\begin{array}{l}\text { Faulkner } \\
(2009 a)^{*}\end{array}$ & 60 & $\begin{array}{c}\text { Engineering } \\
\text { Studies }\end{array}$ & $\begin{array}{c}\text { United } \\
\text { Kingdom and } \\
\text { United States }\end{array}$ & $\begin{array}{c}52 \text { engineers } \\
\text { (33 men, } 19 \\
\text { women) in } \\
\text { software } \\
\text { development, } \\
\text { building } \\
\text { design, and } \\
\text { oilfield } \\
\text { service } \\
\text { companies }\end{array}$ \\
\hline
\end{tabular}




\begin{tabular}{|c|c|c|c|c|}
\hline Faulkner (2009b) & 65 & $\begin{array}{c}\text { Engineering } \\
\text { Studies }\end{array}$ & $\mathrm{N} / \mathrm{A}$ & $\mathrm{N} / \mathrm{A}$ \\
\hline $\begin{array}{l}\text { Cech \& } \\
\text { Waidzunas } \\
(2011)^{*}\end{array}$ & 38 & $\begin{array}{c}\text { Engineering } \\
\text { Studies }\end{array}$ & $\begin{array}{l}\text { Competitive } \\
\text { public } \\
\text { university in } \\
\text { western U.S. }\end{array}$ & $\begin{array}{c}13 \text { LGB } \\
\text { undergraduate } \\
\text { and } 4 \text { LGB } \\
\text { graduate } \\
\text { students (11 } \\
\text { gay, } 4 \\
\text { bisexual, } 2 \\
\text { lesbian) }\end{array}$ \\
\hline $\begin{array}{l}\text { Kyriakidou } \\
(2011)^{*}\end{array}$ & 6 & $\begin{array}{l}\text { Equity, Diversity } \\
\text { and Inclusion: An } \\
\text { International } \\
\text { Journal }\end{array}$ & Greece & $\begin{array}{l}33 \text { prominent } \\
\text { Greek women } \\
\text { engineers in } \\
\text { construction } \\
\text { management } \\
\text { careers } \\
\end{array}$ \\
\hline Holth $(2014)^{*}$ & 3 & $\begin{array}{c}\text { NORMA: } \\
\text { International } \\
\text { Journal for } \\
\text { Masculinity Studies }\end{array}$ & Sweden & $\begin{array}{c}24 \text { computer } \\
\text { and } \\
\text { mechanical } \\
\text { engineering } \\
\text { graduates (15 } \\
\text { women, } 9 \\
\text { men); } 22 \text { IT } \\
\text { consultants } \\
\text { (11 women, } \\
11 \text { men) }\end{array}$ \\
\hline $\begin{array}{c}\text { Saavedra, Araujo, } \\
\text { Manuel e } \\
\text { Oliveira, \& } \\
\text { Stephens }(2014) *\end{array}$ & 2 & $\begin{array}{l}\text { Women's Studies } \\
\text { International } \\
\text { Forum }\end{array}$ & Portugal & $\begin{array}{l}39 \text { women } \\
\text { engineers ( } 20 \\
\text { recently } \\
\text { employed, } 19 \\
\text { with } 10+ \\
\text { years of work } \\
\text { experience) }\end{array}$ \\
\hline
\end{tabular}




\begin{tabular}{|c|c|c|c|c|}
\hline $\begin{array}{c}\text { Cech \& } \\
\text { Waidzunas } \\
(2015)^{*}\end{array}$ & 0 & $\begin{array}{l}\text { Proceedings from } \\
2015 \text { American } \\
\text { Society for } \\
\text { Engineering } \\
\text { Education Annual } \\
\text { Conference \& } \\
\text { Exposition }\end{array}$ & $\begin{array}{l}\text { Competitive } \\
\text { public } \\
\text { university in } \\
\text { western U.S. }\end{array}$ & $\begin{array}{c}13 \text { LGB } \\
\text { undergraduate } \\
\text { and } 4 \text { LGB } \\
\text { graduate } \\
\text { students (11 } \\
\text { gay, } 4 \\
\text { bisexual, } 2 \\
\text { lesbian) }\end{array}$ \\
\hline $\begin{array}{l}\text { Yoder \& Mattheis } \\
(2016)^{*}\end{array}$ & 1 & $\begin{array}{c}\text { Journal of } \\
\text { Homosexuality }\end{array}$ & $\begin{array}{c}\text { United States, } \\
\text { Canada, Great } \\
\text { Britain, and } \\
\text { Australia }\end{array}$ & $\begin{array}{c}1427 \text { survey } \\
\text { respondents } \\
(48 \% \text { women, } \\
44 \% \text { men, } 7 \% \\
\text { trans*, } 4 \% \\
\text { androgynous, } \\
9 \% \\
\text { genderqueer; } \\
40 \% \text { gay, } 22 \% \\
\text { lesbian, } 23 \% \\
\text { bisexual; } 24 \% \\
\text { queer) }\end{array}$ \\
\hline
\end{tabular}




\section{References}

1. Brawner, C. B., Camacho, M. M., Lord, S. M., Long, R. A., \& Ohland, M. W. (2012). Women in industrial engineering: Stereotypes, persistence, and perspectives. Journal of Engineering Education, 101(2), 288318.

2. Buck, H. J., \& Gammon, A. R., \& Preston, C. J. (2014). Gender and geoengineering. Hypatia, 29(3), 651-669.

3. Butler, J. (1990). Gender trouble: Feminism and the subversion of identity. London, UK: Routledge.

4. Cech, E. A. (2013). Ideological wage inequalities? The technical/social dualism and the gender wage gap in engineering. Social Forces, 1-36.

5. Cech, E. A., Rubineau, B., Silbey, S., \& Seron, C. (2011). Professional role confidence and gendered persistence in engineering. American Sociology Review, 76(5), 641-666.

6. Cech, E. A., \& Waidzunas, T. J. (2011). Navigating the heteronormativity of engineering: The experiences of lesbian, gay, and bisexual students. Engineering Studies, 3(1), 1-24.

7. Cech, E. A., \& Waidzunas, T.J. (2015). "Engineers who happen to be gay": Lesbian, gay, and bisexual students' experiences in engineering. In Proceedings from the 2015 American Society for Engineering Education Annual Conference \& Exposition. Seattle, WA.

8. Crenshaw, K. (1991). Mapping the margins: Intersectionality, identity politics, and violence against women of color. Stanford Law Review, 43(6), 1241-1299.

9. de Pillis, E., \& de Pillis, L. (2008). Are engineering schools masculine and authoritarian? The mission statements say yes. Journal of Diversity in Higher Education, 1(1), 33-44

10. Du, X., \& Kolmos, A. K. (2007). Gender inclusiveness in engineering education: Is problem-based learning environment a recipe? In Proceedings from the 2007 American Society for Engineering Education Annual Conference \& Exposition. Honolulu, HI.

11. Faulkner, W. (2000). Dualisms, hierarchies, and gender in engineering. Social Studies of Science, 30(5), 759792.

12. Faulkner, W. (2001). The technology question in feminism: A view from feminist technology studies. Women's Studies International Forum, 24(1), 79-95.

13. Faulkner, W. (2007). "Nuts and bolts and people:" Gender-troubled engineering identities. Social Studies of Science, 37(3), 331-356.

14. Faulkner, W. (2009). Doing gender in engineering workplace cultures. I. Observations from the field. Engineering Studies, 1(1), 2009.

15. Faulkner, W. (2009). Doing gender in engineering workplace cultures. II. Gender in/authenticity and the in/visibility paradox. Engineering Studies, 1(3), 2009.

16. Foor, C. E., \& Walden, S. E. (2009). "Imaginary engineering" or "re-imagined engineering": Negotiating gendered identities in the borderland of a college of engineering. NWSA Journal, 21(2), 41-64.

17. Hatmaker, D. M. (2013). Engineering identity: Gender and professional identity negotiation among women engineers. Gender, Work and Organization, 20(4), 382-396.

18. Holth, L. (2014). Passionate men and rational women: Gender contradictions in engineering. Nordic Journal for Masculinity Studies, 9(2), 97-110. 
19. Kyriakidou, O., \& Kyriakidou, O. (2011). Negotiating gendered identities through the process of identity construction: Women managers in engineering. Equality, Diversity, and Inclusion: An International Journal, 31(1), 27-42.

20. Lagesen, V. A., \& Sørensen, K. H. (2009). Walking the line? The enactment of the social/technical binary in software engineering. Engineering Studies, 1(2), 129-149.

21. Leyva, L. (accepted). Unpacking the male superiority myth and masculinization of mathematics at the intersections: A review of research on gender in mathematics education. To appear in the Journal for Research in Mathematics Education.

22. Leyva, L., \& Battey, D. (under revision). A framework for understanding whiteness in mathematics education.

23. Leyva, L., Massa, J., \& Battey, D. (in preparation). Queering engineering: A critical analysis of the gendered technical/social dualism in engineering and engineering education research.

24. Lynch, I., \& Nowosenetz, T. (2009). An exploratory study of students' constructions of gender in science, engineering, technology. Gender and Education, 21(5), 567-581.

25. Paretti, M. C. (2013). Negotiating masculine spaces: Attitudes and strategies of first-year women in engineering. In Proceedings from the 2013 ASEE Annual Conference \& Exposition. Atlanta, GA.

26. Phipps, A. (2007). Re-inscribing gender binaries: Deconstructing the dominant discourse around women's equality in science, engineering, and technology. The Sociological Review, 55(4), 2007.

27. Riley, D., Pawley, A., Tucker, J., \& Catalano, G. D., (2009). Feminisms in engineering education: Transformative possibilities. NWSA Journal, 21(2), 21-40.

28. Roeser, S. (2012). Emotional engineers: Toward morally responsible design. Science and Engineering Ethics, $18(1), 103-115$.

29. Saavedra, L., Araújo, A. M., de Oliveira, J. M., \& Stephens, C. (2014). Looking through glass walls: Women engineers in Portugal. Women's Studies International Forum, 45(2014), 27-33.

30. Sagebiel, F., Dahmen, J., Davidsson, B., Godfroy-Genin, A., Rommes, E., Thaler, A., \& Urbanciková, N. (2008). Motivation of young people for studying SET. The gender perspective. In Proceedings from the 2008 SEFI Annual Conference, Aalborg, Denmark.

31. Weaver-Hightower, M. (2003). The "boy turn" in research on gender and education. Review of Educational Research, 73, 471-498.

32. Yoder, J. B., \& Mattheis, A. (2016). Queer in STEM: Workplace experience reported in a national survey of LGBTQA individuals in science, technology, engineering, and mathematics careers. Journal of Homosexuality, 63(1), 1-27. 